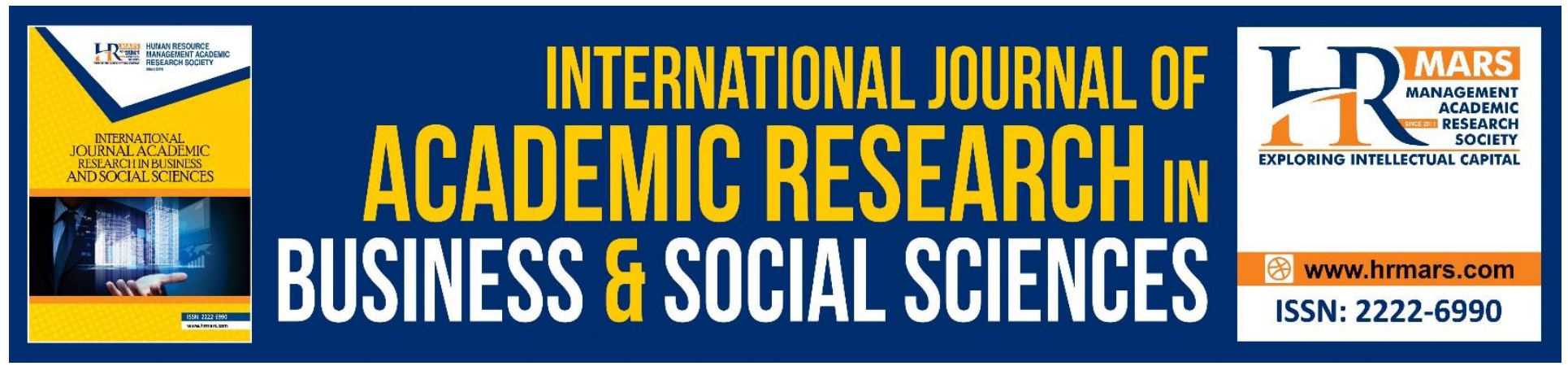

\title{
Influence Of Cross Cultural Differences on International Marketing
}

\author{
Sunday Ewah \& Joseph E. Osang
}

To Link this Article: http://dx.doi.org/10.6007/IJARBSS/v8-i7/4347

DOI: $\quad 10.6007 /$ IJARBSS/v8-i7/4347

Received: 28 May 2018, Revised: 19 June 2018, Accepted: 29 June 2018

Published Online: 25 July 2018

In-Text Citation: (Ewah \& Osang, 2018)

To Cite this Article: Ewah, S., \& Osang, J. E. (2018). Influence Of Cross Cultural Differences on International Marketing. International Journal of Academic Research in Business and Social Sciences, 8(7), 363-376.

Copyright: (C) 2018 The Author(s)

Published by Human Resource Management Academic Research Society (www.hrmars.com)

This article is published under the Creative Commons Attribution (CC BY 4.0) license. Anyone may reproduce, distribute, translate and create derivative works of this article (for both commercial and non-commercial purposes), subject to full attribution to the original publication and authors. The full terms of this license may be seen at: http://creativecommons.org/licences/by/4.0/legalcode

Vol. 8, No. 7, July 2018, Pg. 363 - 376

http://hrmars.com/index.php/pages/detail/IJARBSS

JOURNAL HOMEPAGE

Full Terms \& Conditions of access and use can be found at http://hrmars.com/index.php/pages/detail/publication-ethics 


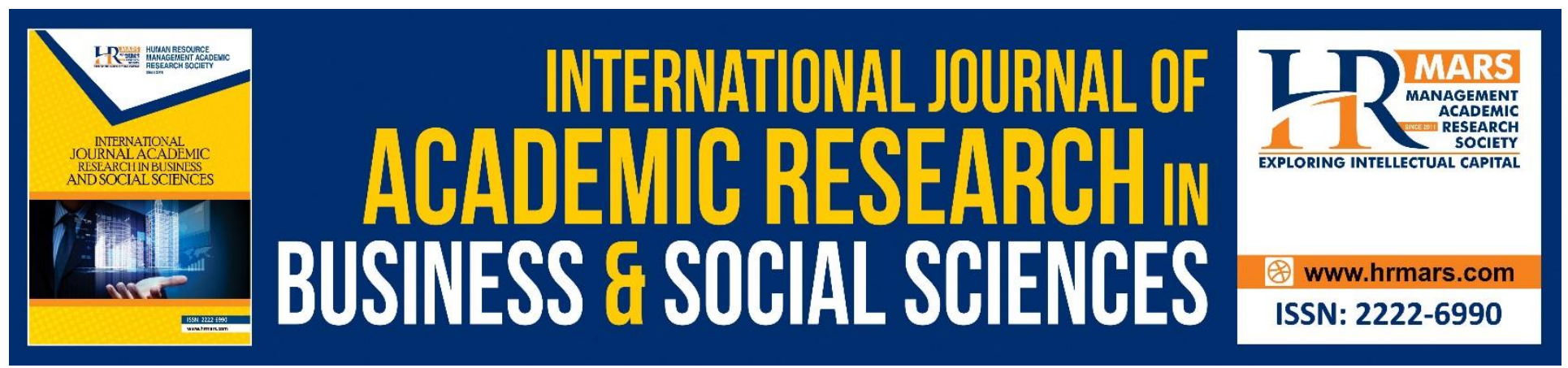

\title{
Influence Of Cross Cultural Differences on International Marketing
}

\author{
Sunday Ewah, Ph.D \& Joseph E. Osang \\ Cross River University of Technology, Faculty of Management Sciences, Ogoja Campus. Cross River \\ State, Nigeria \\ Email: soniewah@yahoo.com
}

\begin{abstract}
The paper is premised on the influence of cross cultural differences (CCD) in foreign markets. International or foreign marketing is the trading of goods and services across national boundaries of nations. To achieve the set objectives questions were formulated in CCDs questionnaires and administered to 1200 selected firms /marketers in the seven continents of the world, via online interactive session and responses questionnaires. The two hypotheses formulated for the study were tested using the Pearson Product Moment Correlation Coefficient and the result shows that the knowledge of CCDs improves firm's sales potentials in foreign markets and the self reference criterion (SRC) often impact negatively on most firms' sales especially in foreign markets. Furthermore, the degree of involvement in foreign or international marketing by most companies/marketers varies widely based on their orientation and philosophy, such as ethnocentrism, polycentrism, regioncentrism and geocentrism. Consequently the sensitivity to and tolerance for CCDs in consumption pattern or attributed meanings to products and services is a highly desirable trait for remaining competitive in foreign/international marketing. This is because firms/marketers will capitalize on the above decision/policy and develop products that appeal to foreign markets that have heterogeneous cultures and needs they are not attuned.
\end{abstract}

Keywords: Foreign Market, CCDs, SRC, Firms Orientation and Marketers.

\section{Introduction}

The remarkable growth of the global economy over the past years has been shaped by the dynamic interplay of various driving and restraining forces. During most of these decades, companies from different parts of the world in different industries achieved great success by pursing, domestic, international, multinational or global marketing strategies. But with the recent changes and sophisticated marketing techniques in the present business world have presented unprecedented challenges to the previous ways of doing business. Today, the growing importance of global marketing stems from the fact that driving forces have more momentum than restraining forces. When firms, corporate organizations, individuals and countries decide to market their products and services beyond the domestic environment it means they are engaged in foreign or international 
INTERNATIONAL JOURNAL OF ACADEMIC RESEARCH IN BUSINESS AND SOCIAL SCIENCES Vol. 8, No. 7, July 2018, E-ISSN: 2222-6990 @ 2018 HRMARS

marketing. It is often not only sufficient to market products and services outside ones territorial boundaries or companies immediate environment but also necessary each country's cultural trait and nuances that the firms or marketers intend to serve should be studied and familiar with. This is as a result of the fact that cultural factors play important role and function as invisible barriers to success. The company or exporter that is engaged in international marketing should not assume that one's own cultural trait will be exactly the same with others in other countries he is doing business. The world market has heterogeneous consumers who are often separated by cultural differences, hence the cultural context of the countries where a company is doing business must be considered paramount. This is because it could work to the detriment or success of a company's brand and business relationship. Moreover, cultural differences between nations, regions, and ethnic groups, far from being extinguished are becoming stronger, therefore international marketers and firms must be vigilant enough to capitalize on salient opportunities while cushioning the effect of adverse threats. The era of mere wishing that products or services will sell or do well and generate reasonable profit despite where the firm market such are gone, much has to be done in terms of conducting a holistic study of the cross cultural traits of the markets if the company has to attend to their needs. A critical analysis of the global economy clearly indicates that most domestic markets are already saturated, and the products produced in such countries need to be sold where the companies can find ready market outside the home market. This gives the exporters, marketers or companies no other option than to explore other emerging markets of the world. In doing so means the companies or marketers have to reach out to other potential consumers or buyers in other countries with the desired population and enhanced purchasing power. The bottom line here is that for companies or marketers to achieve success and attain desired goal there should be an understanding of the differences in cultural meanings in various societies and markets and develop marketing strategies that will be effective in the different cultures. For instance foreign markets have become important for United State film industry because domestic ticket sales have been relatively flat over the years. Film companies have looked to foreign markets for growth and this has yielded positive result. But then, film companies in US are under pressure to develop films that appeal to both their domestic market and foreign consumers (Cateora and Graham, 2002) Appeal here is a function of cultural undertone. Furthermore in Nigeria, most developed countries and the Asian Tiger countries have realized that our culture in terms of parading foreign products cannot be under estimated, hence the deliberate mass production in their home market for the ever ready market in Nigeria. Whether the product quality is

compromised or not that is quite negligible, they count on our, habitual consumption pattern and materialistic tendencies. But also it is important to state that the driving forces such as cultural trait, technology, market needs, economic integration, strategic intent, etc, gave the current impetus to consider the influence of cross cultural traits on international marketing even though the study is anchored on cultural trait. The remaining part of the paper is divided to theoretical conceptualization, marketing entry orientation and degree of involvement, cases of cross cultural differences, the interplay between self reference criterion (SRC) and ethnocentrism frame of reference (EFR) others are methodology of the study, data analysis and discussion of findings, Test of hypotheses, summary of major findings and conclusion, and policy statement.

\section{Theoretical Conceptualization}

International marketing is the performance of business activities designed to plan, price, promote and direct the flow of a company's goods and services to consumers or users in more than one nation 
INTERNATIONAL JOURNAL OF ACADEMIC RESEARCH IN BUSINESS AND SOCIAL SCIENCES Vol. 8, No. 7, July 2018, E-ISSN: 2222-6990 @ 2018 HRMARS

for a profit (Cateora, Graham and Salwan 2010). It means the extension of business activities in more than one nation for a profit for buyers and consumers around the world with Different need that require understanding of their different cultural background. Consequently national culture is a critical factor affecting cross national trade, because culture is pervasive in all marketing activities, such as pricing, promotion, channel of distribution, product, packaging and styling. The company's effort and products are judged in a cultural context for acceptance, resistance or rejection. How such efforts interact with culture determines the degree of success or failure of the international marketer's effort (cateora and Graham 2002). It is imperative for foreign marketers to learn to appreciate the intricacies of cultures different from their own if they are to be effective in a foreign market.

In cross-border marketing, companies and marketers step into different cultural environments characterized by unfamiliar language, distinctive motivations, and different values. Cultural traits therefore implies the learned, shared and enduring orientations of a society which are expressed in value, ideas, attitudes, behaviours and other meaningful symbols and artifact. It is the collective mental programming of people and influences consumer behaviour, marketing manager effectiveness and the range of value-chain operations such as product and service design, marketing and sales. Marketers need to develop understanding and skills in dealing with other cultural traits, because they matter in international marketing especially if the need arises for the development of products and services, interact with foreign business partners, selecting foreign distributors, dealing with customers, preparing for trade deals, and preparing promotional materials (keegan, and Bodo.2000). Marketing across cultures requires a high level of sophistication due to the enormous challenges posed by cultural nuances and other regulatory requirement which strongly influence the selling effort of exporters or companies, hence there is the need to develop proficiency in understanding foreign cultures and to leverage these cultural skills to maximize the performance of both domestic and foreign operators (Reid, 1995).

\section{Marketing Entry Orientation and Degree of Involvement}

Considering the myriad of uncontrollable external factors that hinder the performance of international marketing amongst different firms and countries, some decides to penetrate foreign markets based on the following orientation and degree of involvement; ethnocentrism, polycentrism, regioncentrism, and geocentrism.

1. Ethnocentrism: This is a home country orientation. Having the believed that the home country product or firm is superior compared to the rest of the world products. The assumption is that there are similarities in markets and if a product sells itself or does well in domestic market, certainly the product will do well in the world market. Ethnocentric companies that do conduct business outside the home country are described as international companies; they adhered to the notion that the products that succeed in terms of sales in domestic market are superior and therefore can be sold every where without adaptation. Marketers and companies with ethnocentric tendencies view foreign markets as being subordinate to domestic markets and a means of disposing surplus domestic productions (Chen, 1999). The ethnocentric company is centralized in its marketing management. Plans for international markets are developed utilizing policies and procedures identical to those applied at home market, not minding the differences in consumers' preferences in the world market.

2. Polycentrism: Marketers and firms with polycentric philosophy believe in the uniqueness and the characteristics of the host country where marketing activities are carried out. The 
INTERNATIONAL JOURNAL OF ACADEMIC RESEARCH IN BUSINESS AND SOCIAL SCIENCES

Vol. 8, No. 7, July 2018, E-ISSN: 2222-6990 @ 2018 HRMARS

aforementioned lay the ground work for each subsidiary or multinational company to develop its own unique business and marketing strategies in order to succeed. The polycentric company is decentralized in its marketing management policy. The underlying assumption of the polycentric approach is that there are so many differences in cultural, economic, and marketing conditions in the world that it is impossible and futile to attempt to transfer experience across national boundaries.

3. Regioncentrism: A company or market with a regioncentric orientation place emphasis on the uniqueness of the various regions and seeks to develop an integrated regional strategy for the business. Thus regioncentrism implies a marketer who is willing to have a world view policy that affects marketing products from a regional perspective. On the other hand the world outside the region of interest is often viewed with ethnocentrism or polycentrism or a combination of the two orientations (Keegan, et al, 2000). The essence of firms using this strategy is to strengthen their regional competitiveness rather than moving directly to develop global responses to changes in the competitive environment.

4. Geocentrism: The term geocentrism implies a marketer whose business ideals and innovativeness are tailored towards the world market. The geocentric orientation represents a synthesis of ethnocentrism and polycentrism, which is a world view marketing policies that consider similarities and differences in markets and countries, and seeks to create a global strategy that is fully responsive to both local and foreign needs and wants.

Figure 1 Marketers and Companies Entry Orientations

\section{Ethnocentric Orientation}

\section{Polycentric Orientation}

Home country is superior and there are similarities in foreign markets or countries. This means the companies see only similarities in markets and assume the products and practices that succeed in the domestic market will be successful or excel anywhere in the world, due to their demonstrated superiority.

Marketing implication. Such companies lack adaptation and can never survive in today's business world with people with diverse cultural background.

Each host country is unique and there are differences in foreign markets or countries. It describes companies and marketers unconscious belief or assumption that each country in which they operate or do business is unique.

Marketing Implication: This require each subsidiary to develop its own peculiar business or products and marketing strategies

\section{Regioncentric Orientation}


INTERNATIONAL JOURNAL OF ACADEMIC RESEARCH IN BUSINESS AND SOCIAL SCIENCES Vol. 8, No. 7, July 2018, E-ISSN: 2222-6990 (c) 2018 HRMARS

Marketing Implication: Develop an integrated regional marketing strategy that can serve both the homogeneous and heterogeneous markets and their cultures.

\section{Geocentric Orientation}

Companies that share this philosophy view the entire world as a potential market to be explored. These companies recognizes the fact that there are similarities and differences in domestic and foreign markets or countries.

Marketing Implication: Companies and marketers have to develop integrated world market strategies, while recognizing the diverse culture nuances.

\section{Cases of Cross Cultural Differences}

It is important to note that religion is part and parcel of any society's culture that has significant influence on international marketing operations. For example Mc Donald's and Coca-cola unfortunately offended Muslims sometimes ago by putting the Saudi Arabian flag on their packaging. The flag's design contains a passage from the Koran and Muslims felt their Holy Writ should never be wadded up and thrown away. (Nickels, Mc Hugh, and Mc hugh, 1999). In Islamic countries, dawn-todusk fasting during Ramadan causes workers output to drop because these workers are expected to pray at list five times daily, instead of busy working in the factory to increase production. The work of Nickels, et al (1999) made us to realized that an

American manager in Islamic Pakistan toured a new plant under his control in full operation, and went to his office to make some preliminary forecasts of production. As he was working, suddenly all the machinery in the plant stopped. He thought there was a possible power failure but later realized that his production workers were on their prayer rugs. He returned to his office and proceeded to lower his production estimates. Cultural differences also have impact on such important business factors as human resources management in a global sense. In Latin American countries, workers believe that managers are placed in position of authority to make decision on what to produce, for whom, and be responsible for the welfare of the employees under their control. But one American manager in Peru who neglected his important cultural characteristics and believed workers should participate in managerial functions. This manager was convinced he could motivate his worker to higher levels of productivity by instituting a more democratic decision-making style. Shortly after his new style was put in place, workers began quitting their jobs in droves. The Peruvian workers believed that the new production manager did not know his job and was asking the workers what to do (Srodes, 2000). As far as international marketing is concern some companies have developed universal appeals and recognition such as Coca-cola, Disney, IBM, Ford and Toyota. Unfortunately others have hit the hurdles and stumbled because they refused to adapt to cultural traits of countries they do business with. Start Cateora and Graham (2002) noted that white colour is a symbol of mourning in parts of Asia while Western and Nigeria culture permit the use of white colour for sewing bridal gowns. Furthermore, time conscious Americans are not prepared to understand the meaning of time to Latin Americans or Nigerians. Cross cultural misunderstandings can also occur when a simple hand gesture has a number of different meanings in different parts of the world, before the emergence of Ebola Virus. To signify something is okay, most marketers in United States and Nigeria 
INTERNATIONAL JOURNAL OF ACADEMIC RESEARCH IN BUSINESS AND SOCIAL SCIENCES Vol. 8, No. 7, July 2018, E-ISSN: 2222-6990 @ 2018 HRMARS

raise a hand and make a circle with thumb or forefinger. However this same hand gesture means zero or worthless to the French business man, money to the Japanese and general sexual insult in Sardinia and Greece.(Cataora and Graham 2000) These differences must be learned to avoid misunderstanding that can lead to marketing failures because cultural conditions is like an iceberg that require foreign marketers to constantly guard against measuring and assessing the markets against the fixed values and assumptions of their domestic market and cultures.

The Interplay between self Reference Criterion (SRC) and Ethnocentrism Frame of Reference (EFR)

The primary obstacles to success in international marketing are person's self-reference criterion (SRC) and an associated ethnocentrism. SRC is an unconscious reference to one's own cultural values, experiences, and knowledge as a basis for decision making. While ethnocentrism is the notion that one's own culture or company knows best how to do things. Ethnocentrism is generally a problem when managers from affluent countries work with managers and markets in less affluent countries (Chen, 1999). Both the SRC and ethnocentrism impede the ability to assess a foreign market in its true light. When confronted with a set of facts, we react spontaneously on the basis of knowledge that is a product of the history of our culture. We seldom stop to think about a reaction; we simply react. Thus, when faced with a problem in another culture, the tendency is to react instinctively and refer to our SRC for a solution. Our reaction, however, is based on meanings, values, symbols, and behaviour relevant to our own culture and usually different from those of the foreign culture. Such decisions are often not good ones (Jevons, 2000).

To illustrate the impact of the SRC. Consider misunderstandings that can occur about personal space between people of different cultures. In the United States, unrelated individuals keep a certain physical distance between themselves and others when talking or in groups. We do not consciously think about that distance; we just know what feels right without thinking. When someone is too close or too far, we feel uncomfortable and either move far away or get closer to correct the distance. In doing so we are relying on our SRC. In some cultures the acceptable distance between individuals is substantially less than that which is comfortable for Americans. When someone from another culture approaches an American too closely, the American, unaware of that culture's acceptable distance, unconsciously reacts by backing away to restore the proper distance (i.e. proper by American standards ), and confusion result for two parties. Americans assume foreigners are pushy, while foreigners assume Americans are unfriendly and literally "standoffish." Both react according to the values of their own SRCs, making both victims of a cultural misunderstanding (Reid, 1995)

Your self-reference criterion can prevent you from being aware that there are cultural differences or from recognizing the importance of those differences. Thus you might fail to recognize the need to take action, you might discount the cultural differences that exist among countries, or you might react in a situation in a way offensive to your hosts. A common mistake made by Americans is to refuse food or drink when offered. In the United States, a polite refusal is certainly acceptable, but in Asia or Middle East, a host is offended if you refuse hospitality. Although you do not have to eat or drink much, you do have to accept the offering of hospitality (Cateora and Graham, 2002). Understanding and dealing with the self-reference criterion are two of the more important facets of international marketing.

Ethnocentrism and SRC can influence an evaluation of the appropriateness of a domestically designed marketing mix for a foreign market. If marketers are not aware, they might evaluate a marketing mix based on experiences (i.e. their SRC without full appreciating the cultural difference that requires adaptation. 
INTERNATIONAL JOURNAL OF ACADEMIC RESEARCH IN BUSINESS AND SOCIAL SCIENCES Vol. 8, No. 7, July 2018, E-ISSN: 2222-6990 @ 2018 HRMARS

The most effective way to control the influence of ethnocentrism and SRC is to recognize their effects on our behavior. Although it is almost impossible for someone to learn every culture in depth and to be aware of every important differences, an awareness of the need to be sensitive to differences and to ask questions when doing business in another culture can help one avoid many of the mistakes possible in international marketing. Marketers into false sense of apparent sameness. This apparent, coupled with the self-reference criterion, is often the cause of international marketing problems. Undetected similarities do not cause problems: however, the one difference that goes undetected can create a marketing failure.

\section{Methodology of the Study}

The accessible population of study comprises a total of 1200 respondents/firms in seven continents (ie Africa, Asia, Antarctica, Australia, Europe, North America and South America) of the world. The justification for the choice of these firms/respondents was strictly judgmental and based on the magnitude of involvement in international marketing activities. The research instrument Cross Cultural Difference Questionnaire (CCDQ) was designed by the researchers and vetted and satisfied fit for use by renowned scholars in marketing research, quantitative techniques and statistics in the Ivory tower. The CCDQ was administered to this group of interest using online mail to elicit data/information for the study. The questions were designed in the form of agreed and disagreed options.

The techniques used in analyzing the operational data was the simple percentage and all the hypotheses formulated for the study were tested using the Pearson Product Moment Correlation Coefficient

This statistical tool seeks to establish the strength or degree of association between the dependent and independent variables. The formula is expressed thus;

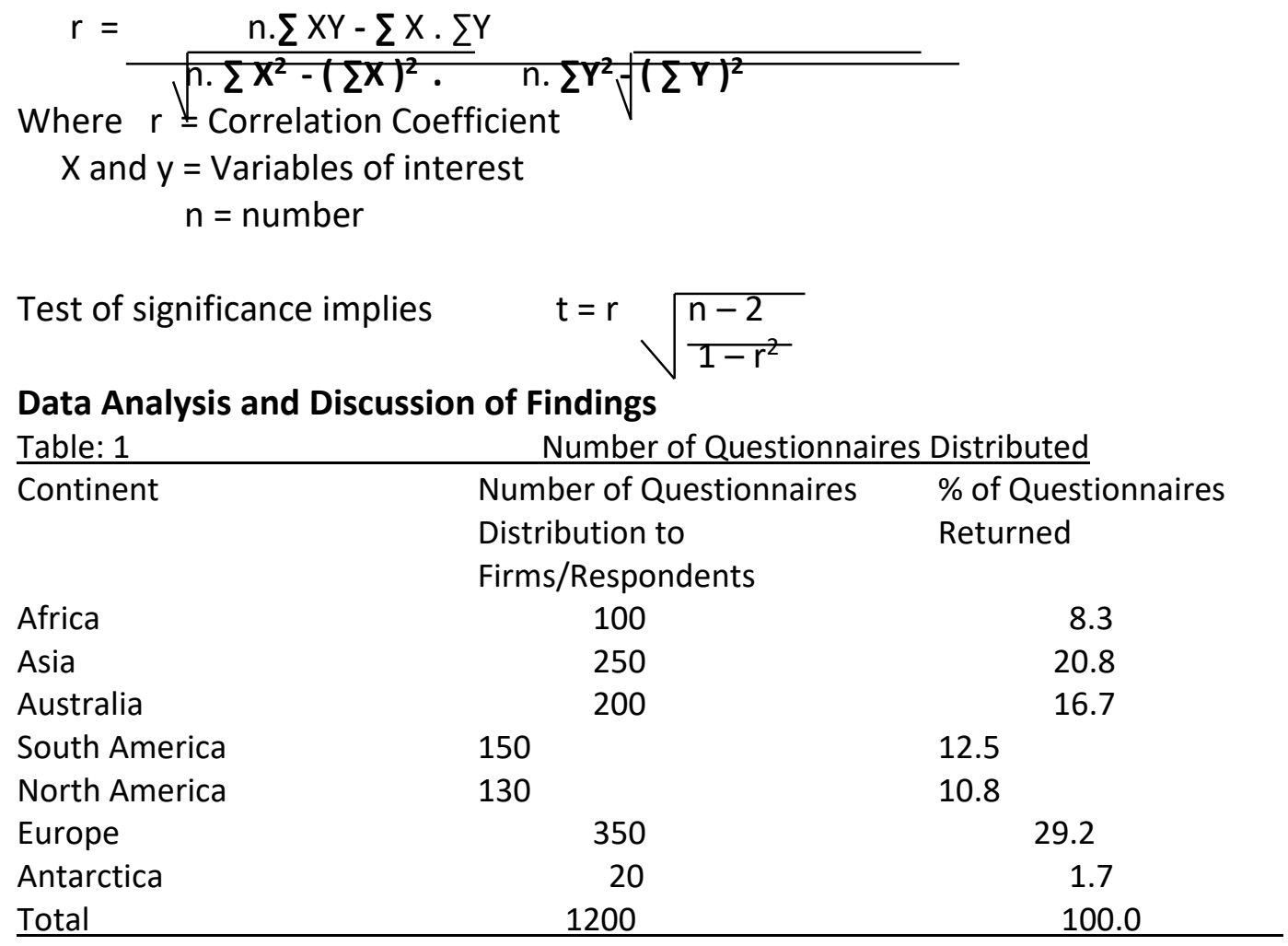

Source: Researchers' Field Work, 2017 
INTERNATIONAL JOURNAL OF ACADEMIC RESEARCH IN BUSINESS AND SOCIAL SCIENCES

Vol. 8, No. 7, July 2018, E-ISSN: 2222-6990 @ 2018 HRMARS

The researchers through the administration of online questionnaire had the following results. Africa had a total of 100 (8.3\%) administered questionnaires to firms and respondents. Asia's number of questionnaires administered to respondents/firms were 250 (20.8\%). Australia also had 200 (16.7\%) questionnaires administered to different firms and respondents in the continent. South America had 150 (12.5\%) and North America had 130 (10.8\%) respondents/firms respectively. Europe had majority response rate of 350 (29.2\%) of the total number of questionnaires administered to respondents and firms, while the least number of questionnaires were administered to Antarctica 20 (1.7\%). The decision to administer the questionnaires using the above subjective method is not far from the fact that international business transactions are mostly carried out by firms in Europe, America, Asia, Australia, while Africa firms are mostly import oriented. Antarctica remains the least continent both in population and intensity of involvement in foreign marketing. But sufficed to conclude that all the continents views/responses were taken into consideration, which further help to address all the issues raised in the study.

Table 2 Responses Based on Cross Cultural Differences Questionnaire

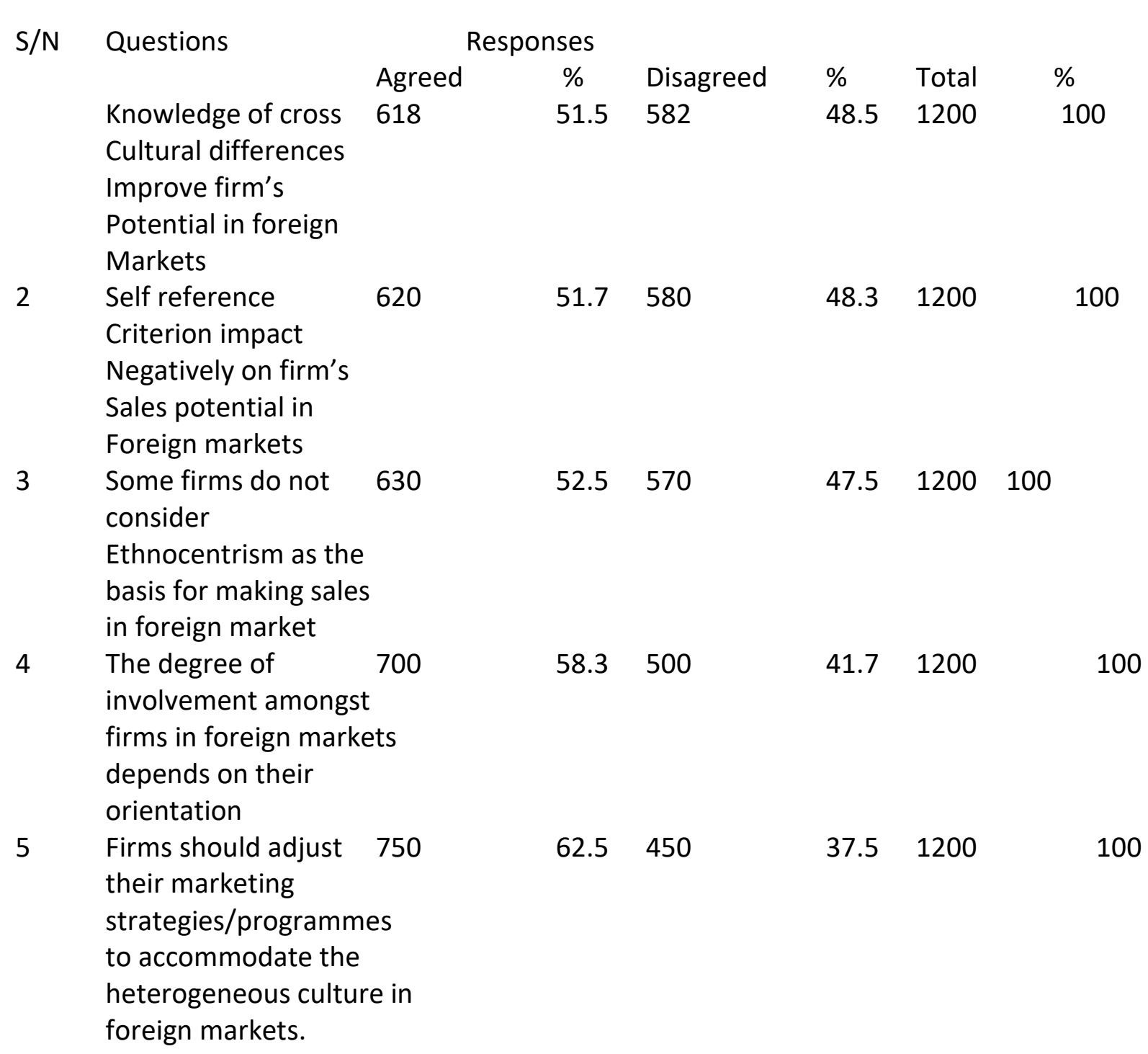


INTERNATIONAL JOURNAL OF ACADEMIC RESEARCH IN BUSINESS AND SOCIAL SCIENCES Vol. 8, No. 7, July 2018, E-ISSN: 2222-6990 @ 2018 HRMARS

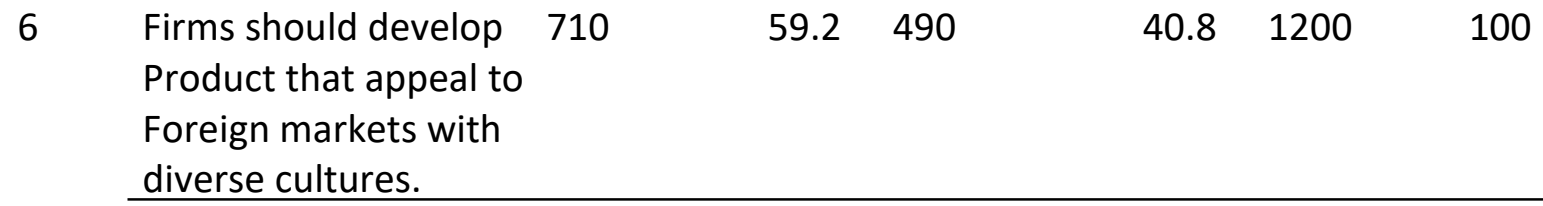

Source: Researchers' Field work, 2017

The result of data analysis in table 2 , clearly shows that in question one, 618 (51.8\%) respondent/firms agreed that the knowledge of cross cultural differences improve firms sales potential in foreign markets. 582 (48.5\%) respondents/firms disagreed. The majority response rate signified that the knowledge of cross cultural difference has significance relationship with firm's sales in foreign markets. The above result was validated when the test of hypothesis was carried out. The findings above do not show any departure from established fact as enunciated by Keegan (2000) in his work that made reference to develop an understanding and skills in dealing with other cultural traits.

Question two gave an insight which depicts that 620 (51.7\%) of the respondents/firms agreed that the Self Reference Criterion (SRC) impact negatively on firm's sales potential in foreign markets, while $580(48.3 \%)$ of respondents/firms disagreed. The result in question two is consistent with Jevons (2000) earlier study that emphasizes the needs for firms and marketers to anticipate the influences of both foreign and domestic uncontrollable factors, such as SRC, an unconscious reference to one's own cultural values which some firms uses as the basis for decision making, may not create a market for firms' products in the world market.

The responses in question three indicates that 630(52.5\%) respondents/firms believed that ethnocentrism should not be used as the basis for gaining reasonable sales margin in foreign markets. The remaining 57 (47.5\%) did not accept the above answer. The work of earlier scholars after having perused various literature made it cleared that companies and firms with ethnocentric tendencies believed that the home country culture, company and product is superior to those of other countries (Chen. 1999).

Question four made us to understand that the degree of involvement amongst firms in international marketing depends on firms' orientation based on 700 (58.3\%) respondents/firms' positive response rate, while the remaining 500 (41.7\%) did not accept. Chen (1999), and Keegan, et al, (2000) confirmed that firms and marketers enter foreign markets bearing in mind their degree of involvement, such as being ethnocentric, polycentric, regioncentric and geocentric in scope/coverage. The result is consistent with earlier scholarly work as discussed by keegan and Bodo (2000) and Chen (1999).

Question five, clearly shows that 750 (62.5\%) respondent/firms agreed that companies and firms should design their marketing strategies and programmes in such a way that will accommodate the diverse/heterogeneous cultures in foreign markets. If it is done more markets will be created for the much envisaged sales. On the other hand 450 (37.5\%) of the respondents/firms disagreed with the earlier assertion. In conclusion the findings are in conformity with the work of Levitt (1983) that markers and firms should develop integrated world marketing strategies while recognizing the diverse culture nuances.

The last research question (six) depicts that 710 (59.2\%) of the respondents/firms agreed that firms and marketers should develop products that appeal to foreign markets while taking cognizance of their diverse cultures. Believing that the home culture does not supersede the foreign culture. The remaining $490(40.8 \%)$ respondents/firms disagreed and had different views contrary to the research earlier result. 
INTERNATIONAL JOURNAL OF ACADEMIC RESEARCH IN BUSINESS AND SOCIAL SCIENCES

Vol. 8, No. 7, July 2018, E-ISSN: 2222-6990 @ 2018 HRMARS

\section{Test of Hypotheses Formulated for the Study}

The study was guided by the following hypotheses stated both in the null ( $\mathrm{Ho}$ ) and alternative $\left(\mathrm{H}_{1}\right)$ form.

Hypothesis One

Ho: knowledge of cross cultural differences does not influence firms' sales potentials in foreign market.

$\mathrm{H}_{1}$ : knowledge of cross cultural differences influence firms' sales potentials in foreign market. Hypothesis Two

Ho: Self references Criterion does not impact negatively on firm's sales potentials in foreign markets.

$\mathrm{H}_{1}$ : Self reference criterion impact negatively on firm's sales potential in foreign markets.

Table: $3 \quad$ Result of Computation of Hypothesis One

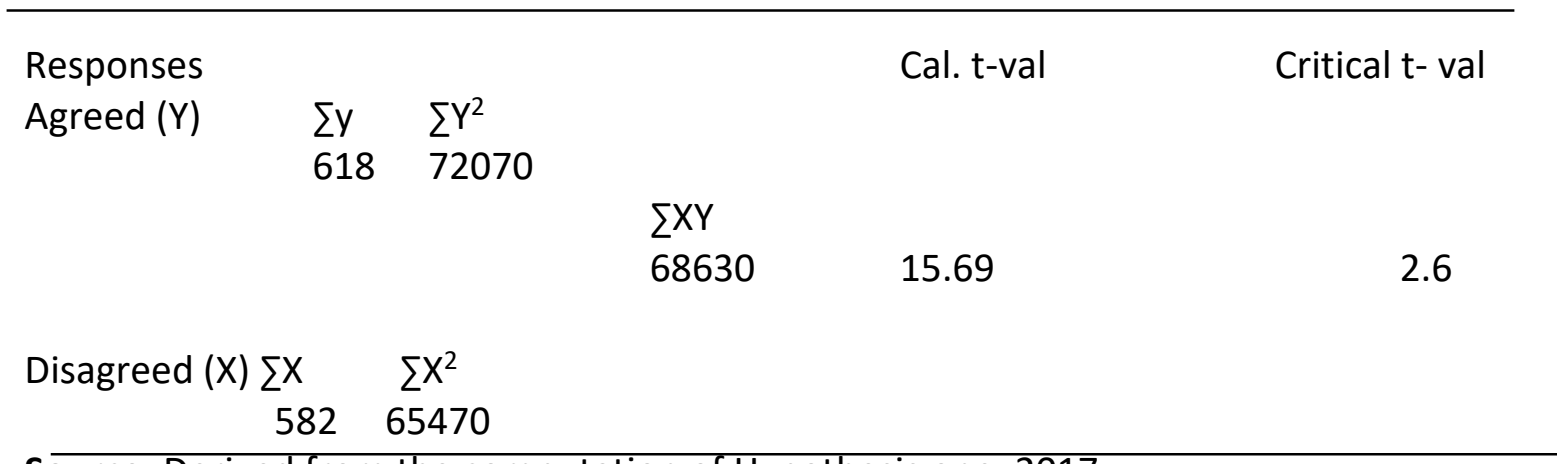

Source: Derived from the computation of Hypothesis one, 2017

Decision Criteria (Cal. t-Val $15.7>$ Cri. t- val. 2.6).

$\mathrm{H}_{1}$ was accepted and $\mathrm{Ho}$ rejected. This result indicates that the calculated table value 15.7 is greater than the Critical table value 2.6 at 0.05 level of significance and 5 degree of freedom in a two tail test. This implies that the knowledge of cross cultural differences influence firms' sales in foreign market.

Table: 4

Result of computation of Hypothesis Two

\begin{tabular}{lllr|l}
\hline Responses & $\sum \mathrm{Y}$ & $\sum \mathrm{Y}^{2}$ & Cal. t-val & Critical t- val \\
Agreed $(\mathrm{Y})$ & 620 & 72200 & &
\end{tabular}

$\sum X Y$

$68620 \quad 15.69$

Disagreed $(X) \sum X \quad \sum X^{2}$

$580 \quad 65279$

Source: Derived from the Computation of Hypothesis Two, 2017

Decision Criteria (Cal. t- val is 15.69 > cri. t-val. 2.57)

$\mathrm{H}_{1}$ was accepted and Ho rejected, because the calculated table value 15.7 is greater than the critical table value 2.57 at 0.05 level of significance and 5 degree of freedom in a two tail test. This result invariably means that the self reference criterion has a negative impact on firms' sales in foreign market. 


\section{Summary of Major Findings and Conclusion}

The study made us to understand that the knowledge of cross cultural differences improves firms performance in foreign markets, this was confirmed when the test of the first hypothesis was carried out. The result of the above findings is consistent with the work of Reid (1995) and Jevons, (2000). Furthermore, the self reference criterion (SRC) has a negative effect on firms' sales potential in foreign markets, as hypothesized and confirmed in the study. The result does not contradict earlier scholars' work, such as Strodes (2000) and Jevons (2000). They all agreed that "SRC" which is an unconscious reference to a firms' or marketers' own cultural values, experiences, conditions and knowledge as basis for business decisions making; which often does not promote firms' sales potentials in international marketing. Some firms and marketers hold to the conviction that ethnocentrism should not be used as the basis for prospecting for sales in international marketing. This is because each firm or company has its production techniques and marketing skills and using ethnocentrism as a yard stick impede the ability to assess foreign market thoroughly. This also confirmed the work of Chen, (1999)

The degree of involvement amongst firms in foreign markets depends on their orientations and scope of operation. The explored literature indicated that some firms are polycentric, regioncentric, geocentric and ethnocentric in orientation/ philosophy and marketers and firms often consider the aforementioned, (Keegan and Bodo 2000). The study concluded with the assertion that firms and marketers should adjust and develop marketing strategies/programmes that accommodate the heterogeneous cultures in foreign markets which lead to the production and selling of products that will be appealing to foreign markets.

\section{Policy Statement}

The influence of cross cultural differences however is the most challenging and important once confronting international marketers and companies. Therefore they must adjust their marketing effort towards acceptance to cultures which they are not familiar. In dealing with unfamiliar markets companies and marketers must be aware of the frames of reference they are using in making decision or evaluating the potentials of markets. This is as a result of the fact that judgment are derived from experience that is the result of acculturation in the home country, where the firms or marketers' operates.

In conclusion the literature related to this study and empirical validation suggest that for the avoidance of errors and failed markets, firms' and marketers should conduct cross cultural analysis (CCA) which requires an understanding of the culture of foreign market as well as the firms or marketer's culture, before walking steps backward to produce and markets products and services for international buyers and consumers.

\section{References}

Cateora, P.R, and Graham, J.L. (2002). International Marketing; Eleventh Edition New York. Mc GrawHill Companies,_Inc.

Chen, Z. (1999) "Marketing Globally: Planning and Practice”. Journal of Interntional Marketing, Vol.7 No.2 Pp.96-98.

Jevons, C. (2000) Misplaced Marketing. Journal of Consumer Marketing, Volume, 17 (1) Pp.7-8 Keegan, W.J. and Bodo, B.S . (2000) Marketing Management: A European Perspective. New York; Prentice Hall International. 
INTERNATIONAL JOURNAL OF ACADEMIC RESEARCH IN BUSINESS AND SOCIAL SCIENCES

Vol. 8, No. 7, July 2018, E-ISSN: 2222-6990 (C) 2018 HRMARS

Levitt, T. (1983) The Globalization of Markets. Harvard Business Review (May-June) Vol. 92

Malnight, T.W. (1995) "Globalization of an Ethnocentric Firm: An Evolutionary Perspective" Strategic Management Journal, Vol. 16 (February) Pp. 119-141.

Miles, G.L (1995) Tailoring a Global Product. International Business Vol. 7, Pp. 50-52

Nickels, W.G, Mchugh, J.M., and Mchugh, S.M. (1999) Understanding Business. $5^{\text {th }}$ Edition, New York. Irwin/Mc Graw-hill Companies Inc.

Reid, D.M (1995) "Perspectives for International Marketers on the Japanese Market" Journal of International marketings. Vol. 3, no 1, Pp. 63-84.

Srodes, J. (2000) Success Depends on Being Globally Literate. World Trade (May) Pp. 14-15

Yip, G. S (1996) Global Strategy as a Factor in Japanese Success. International Executive, Vol. 38 Number 1 (January-February) Pp. 145-167.

Table: Computation of Hypothesis One

\begin{tabular}{lcccrc}
\hline & $Y$ & $X$ & $Y^{2}$ & $X^{2}$ & $X Y$ \\
Africa & 54 & 46 & 2916 & 2116 & 2484 \\
Asia & 128 & 122 & 16384 & 14884 & 15616 \\
Australia & 104 & 96 & 10816 & 9216 & 9984 \\
South America & 75 & 75 & 5625 & 5625 & 5625 \\
North America & 70 & 60 & 4900 & 3600 & 4200 \\
Europe & 177 & 173 & 31329 & 29929 & 30621 \\
Antarctica & 10 & 10 & 100 & 100 & 100 \\
& $\Sigma Y=618$ & $\sum X=582$ & $\sum Y^{2}=72070 \quad \Sigma X^{2}=65470$ & $\sum X Y=68630$ \\
\hline
\end{tabular}

Source: Researchers' Computation 2017

$\frac{r=7 \times 68630-582 \times 618}{\sqrt{7 X 65470-(582)^{2}} \sqrt{7 \times 72070-(618)^{2}}}$
$\frac{480410-359676}{\sqrt{458290-338724} \sqrt{504490-381924}}$
$\frac{120734}{\sqrt{119566 \times \sqrt{122566}}}$
$\frac{120734}{345.78 \times 350.09}=\frac{120734}{121056.71=0.99}$

Test of significant implies ' $\mathrm{t}$ ' $=0.99 \frac{\sqrt{7-2}}{1-0.99} 2=0.99 \frac{\sqrt{5}}{1-0.9801}=0.99 \frac{\sqrt{5}}{0.0199}=0.99 \sqrt{251.26}$ $\mathrm{T}=0.99 \times 15.85=$ which represents calculated value

$\mathrm{DF}=7-2=$ table value 2.57 or 2.6

Table: Computation of Hypothesis two

\begin{tabular}{lrrrrr}
\hline & $Y$ & $X$ & \multicolumn{1}{c}{$Y^{2}$} & \multicolumn{1}{c}{$X^{2}$} & \multicolumn{1}{c}{$X Y$} \\
Africa & 55 & 45 & 3025 & 2025 & 2475 \\
Asia & 128 & 122 & 16384 & 14884 & 15616 \\
Australia & 104 & 96 & 10816 & 9216 & 9984 \\
South America & 75 & 75 & 5625 & 5625 & 5625 \\
North America & 70 & 60 & 4900 & 3600 & 4200 \\
Europe & 177 & 173 & 31329 & 29929 & 30621 \\
Antarctica & 11 & 9 & 121 & 81 & 99
\end{tabular}


INTERNATIONAL JOURNAL OF ACADEMIC RESEARCH IN BUSINESS AND SOCIAL SCIENCES Vol. 8, No. 7, July 2018, E-ISSN: 2222-6990 @ 2018 HRMARS

\begin{tabular}{rlrl}
$\sum Y=620$ & $\sum X=580 \quad \sum Y^{2}=72200 \quad \sum X^{2}=65279 \quad \sum X Y=68620$ \\
\hline
\end{tabular}

Source: Researchers' Computation, 2017

$r=\frac{7 \times 68620-580 \times 620}{\sqrt{7\left(X 65279-(580)^{2}\right.} \sqrt{7 \times 72200-(620)^{2}}}$

$=\frac{480340-359600}{\sqrt{456953-336400} \sqrt{505400-3}}$

$=\frac{4803400}{\sqrt{456953-336400} \sqrt{50500-384400}}$

$=\frac{120740}{\sqrt{120553 X} \sqrt{121000}}=\frac{120740}{347.21 \times 347.85}=\frac{120740}{120776.99}$

$\mathrm{t}=0.99$

test of significant implies ' $\mathrm{t}$ ' $=0.99 \frac{\sqrt{7-2}}{1-0.99} 2=0.99 \frac{\sqrt{5}}{1-0.9801}=0.99 \frac{\sqrt{5}}{0.0199}=0.99 \sqrt{251.26}$ $\mathrm{T}=0.99 \times 15.85=15.69$ which represent the calculated value DF $=7-2=5$ at $0.05 \%=$ critical table value 2.57 